\title{
KAJIAN PERKEMBANGAN ARSITEKTUR POSTMODERN PADA BANGUNAN KOTA MEDAN
}

\author{
Yeshi Ulina Utami Br Ginting ${ }^{1}$, Imam Faisal Pane ${ }^{2}$ \\ Program Studi Magister Teknik Arsitektur Fakultas Teknik Universitas Sumatera Utara \\ Jl. Perpustakaan St. J07 Building, Medan, 20155, Indonesia \\ *Email: ${ }^{\text {} y s g t g . m j s t y @ g m a i l . c o m, ~}{ }^{2}$ raihanpane@yahoo.com
}

\begin{abstract}
Architecture is kind of culture product and civilization in form as a building. Beside the main function as an activities for user, architecture is a result of creativity, taste and human initiative in response from sociocultural condition in a locality community. Post-modern is an architectural style that mixed tradition with the past, and rising style of architectural regionalism. Based on this style, the shape of building fully released and handed over to local architects. To express themselves and be creative on the shape and contents of the building at the regional point they stand. Based on backround, this study will examine is there a building in Medan which responds to the development of post-modern architecture. This study case is based on a literature study with methods such as inventory, descriptive, analysis and interpretation. The results showed that the post-modern architectural concept evolved and applied to new buildings in Medan.
\end{abstract}

Keywords: Architecture Development, Postmodern Architecture, Architecture in Medan.

\section{PENDAHULUAN}

Ada dua jenis wujud kearifan local dibedakan atas: (1) Tangible (Berwujud Fisik), seperti kearifan lokal yang tertuang ke dalam bentuk tulisan dan karya-karya arsitektur; dan (2) Intangible (Tidak Berwujud), kearifan lokal yang tidak berwujud ini dapat ditemui seperti petuah-petuah yang disampaikan secara verbal dan turun-temurun. Kearifan Lokal adalah gagasan-gagasan setempat (lokal) yang bersifat bijaksana, penuh kearifan, bernilai baik, yang tertanam, menjadi tradisi dan diikuti oleh anggota masyarakatnya (Keraf, 2002 dan Ridwan, 2007). Kebudayaan datang dari manusia, ungkapan dirinya, baik dalam hal cara berpikir, cita rasa serta seleranya, yang tentulah bersifat fana dan relatif (Mangunwijaya, 1995). Sejalan dengan ini berkembangnya pula kebudayaan, arsitektur juga berkembang. Sebagaimana aspek budaya yang lain, arsitektur senantiasa berubah dan mengalami evolusi sepanjang masa. Arsitektur merupakan produk budaya dan peradaban manusia dalam bentuk bangunan. Arsitektur merupakan lingkungan binaan yang memenuhi bentuk, struktur ,fungsi, ragam hias dan cara pembuatannya diwariskan secara turun temurun. Pada mulanya sistem hidup manusia berpindah-pindah dari satu tempat ketempat lain. Bangunan yang diciptakan masih berupa tempat berlindung untuk sementara dari pengaruh alam, seperti hujan panas dan lain sebagainya. Disamping fungsi utama sebagai tempat berlindung bagi penggunanya, arsitektur merupakan suatu hasil cipta, rasa, dan karsa manusia sebagai respon terhadap kondisi sosio-kultural pada suatu lokalitas kemasyarakatan wadah kegiatan. Serta dapat di pakai untuk melakukan aktivitas kehidupan dengan sebaik-baiknya.

Permasalahan penelitian yang akan dibahas berhubungan dengan arsitektur postmodern yang berkembang pada Kota Medan. Adapun perumusan masalah dari penelitian ini adalah:

1. Bagaimana perkembangan arsitektur postmodern di Kota Medan?

2. Adakah bangunan di Kota Medan yang merespon perkembangan arsitektur postmodern?

Dengan dirumuskannya permasalahan penelitian, maka ujuan penelitian ini adalah: 
1. Memahami perkembangan post modern di Kota Medan

2. Menemukan bangunan post modern yang ada di Kota Medan

Sehingga nantinya, keluaran dari penelitian ini adalah:

1. Memahami arsitektur postmodern berdasarkan sejarah, tokoh dan bangunan yang menganut karakter desain arsitektur postmodern.

2. Menemukan bangunan di Kota Medan yang merespon perkembangan arsitektur postmodern.

\section{METODE PENELITIAN}

\section{Jenis dan Metoda Penelitian}

Penelitian sederhana ini merupakan sebuah riset deskriptif studi kepustakaan (Library Reseach), yaitu penelitian yang obyek utamanya adalah buku-buku dan literatur lainnya. Pendekatan penulisan yang dipakai dalam melaksanakan penelitian ini adalah dengan grounded theory.

Metoda yang dipakai adalah studi dokumen/literatur, observasi, analisis dan diskusi dengan ahli. Dalam pemiliha lokasi, metoda yang dipakai adalah pemilihan acak salah satu kota yang berkembang di Indonesia. Sedangkan lokasi terpilih adalah kawasan pemukiman yang dapat merepresentasikan bangunan hunian yang ada di kota tersebut. Sehingga peneliti akan me-review bangunan tersebut dengan grounded theory.

\section{Lokasi Penelitian}

Adapun pemilihan lokasi penelitian adalah Kota Medan. Lokasi ini dipilih karena kota ini merupakan salah satu kota berkembang yang ada di Indonesia. Dengan latar belakang sejarah, polotik, budaya dan perkembangan pembangunan yang ada, dirasa tepat jika kota ini dijadikan cerminan terhadap perkembangan arsitektur sekarang ini. Terkhusus perkembangan arsitektur postmodern. Kawasan terpilih yang dapat merepresentasikan bangunan hunian yang ada di Kota Medan adalah Perumahan Taman Setia Budi Indah, Kecamatan Medan Sunggal, Medan, Sumatera Utara.

\section{Populasi dan Sampel}

Adapun populasi dari penelitian ini adalah bangunan yang ada di Kota Medan.
Namun, melihat besarnya populasi, maka peneliti memilih bangunan hunian yang ada di Kota Medan, peneliti akan mengmbil sampel untuk penelitian ini. Teknik pengambilan sampel dalam kasus ini menggunakan probablility sampling (pengambilan sampling secara acak).

\section{Metoda Penentuan Variabel}

Ketepatan pemilihan metoda dalam penelitian sangatlah penting. Maka berdasarkan grand theory yang ada, peneliti mengambil variabel untuk menentukan metoda apa yang dirasa paling tepat untuk memecahkan permasalahan penelitian. Tabel 1 adalah metoda yang digunakan dalam penelitian ini.

Tabel 1. Tabulasi Metoda Penentuan Variabel

\begin{tabular}{|c|c|c|c|}
\hline Teori & Variabel & Metoda & $\begin{array}{c}\text { Data yang } \\
\text { Diperlukan }\end{array}$ \\
\hline $\begin{array}{l}\text { Jehnck } \\
(1977)\end{array}$ & $\begin{array}{l}\text { Ideologi } \\
\text { Metoda } \\
\text { Style } \\
\text { (Gaya) }\end{array}$ & $\begin{array}{l}\text { Studi } \\
\text { literatur, } \\
\text { Observasi } \\
\text { bangunan } \\
\text { Studi } \\
\text { literatur, } \\
\text { Observasi } \\
\text { bangunan } \\
\text { Studi } \\
\text { literatur, } \\
\text { Observasi } \\
\text { bangunan }\end{array}$ & $\begin{array}{l}\text { Teori } \\
\text { terkait: style } \\
\text { Fasad } \\
\text { Bangunan }\end{array}$ \\
\hline
\end{tabular}

\section{HASIL DAN PEMBAHASAN}

\section{Sejarah dan Tokoh Postmodern}

Lahirnya arsitektur postmodern merupakan dialektika kritis terhadap ideologi sebelumnya (modernisme). Posmodernisme merupakan kelanjutan dari modernisme dan trensendernya. Gaya arsitektur modern (international style) dianggap telah mencemari kota-kota diseluruh dunia dengan bentuk kotak yang monoton, dan menciptakan kota tanpa karakter (Adam dan Swandara, 2014; Ra. Wondoamiseno. $1990 \quad$ ). Pada periode berikutnya mulai timbul usaha untuk menggabungkan antara unsur lama dengan unsur baru. Aliran-aliran tersebut antara lain adalah post modernisme (Ra. Wondoamiseno. 1990). Posmodernisme sebagai gerakan budaya tidak berarti memutar jarum jam ke belakang, tetapi merekonstruksikan asumsi-asumsi kaum modernis dengan sesuatu yang lebih besar, lebih 
penuh, dan lebih benar. Sehingga post-modern timbul pada saat aliran modern sudah mencapai klimaks pertumbuhannya dan sebagai suatu aliran baru yang merupakan perubahan dramatis arsitektur modern dan internasional style.

Dalam perkembangan sejarahnya, beberapa tokoh penting yang dapat mendeskripsikan postmodern secara lebih lanjut adalah: (1) Michel Foucault. Paul, Poitiers, 15 Oktober 1926 -Paris 25 Juni 1984. Adalah seorang filsuf asal Perancis. Ia adalah salah satu pemikir paling berpengaruh pada zaman pasca perang dunia II. Foucault mendefinisikan kekuasaan dan sejarah adalah sebagai berikut: Kekuasaan adalah soal praktik-praktik konkrit yang lantas menciptakan realitas dan pola-pola perilaku, memproduksi wilayah objek-objek pengetahuan dan ritual-ritual kebenaran yang khas, praktik-praktik itu menciptakan normanorma yang lalu diproduksi dan dilegitimasi melalui para guru, pekerjasosial, dokter, hakim, polisi dan administrator; (2) Frederich Wilhelm Nietzsche. Rochen, Prusia 15 Oktober 18441900. Menurutnya manusia harus menggunakan skeptisme radikal kemampuan akal. Tidakada yang dapat dipercaya dari akal. Terlalu naïf jika akal dipercaya mampu memperoleh kebenaran. Kabenaran itus endiri tidak ada. (3) Jacqeues Derrida. Al Jazair, 15 Juli 1930-Paris 9 Oktober 2004. Menurutya apa yang dicarimanusia modern selamaini, yaitu kepastian tunggal yang ada didepan, tidakl ah ada dan tidak ada satupun yang bias dijdikan pegangan. Karena satu -satunya yang bias dikatakan pasti, ternyata adalah ketidakpastian atau permainan.

Berdasarkan tokoh yang ada, secara filosofi sesungguhnya post-modern dapat dikatakan sebagai masa dimana kebebasan berlaku. Apa yang kita anggap benar sesungguhnya belum tentu benar bagi orang lain. Tidak ada hal yang pasti. Penalaran, ideology dan latar belakang setiap orang mempengaruhi pola pikirnya. Sehingga hal tersebut akan berimbas, tidak aka nada hal yang sama di dunia ini. Hokum relative terdebut membuat perbedaan yang terjadi adalah buah dari pemikiran setiap orang yang tidak untuk dipersalahkan.

\section{Definisi Arsitektur Modern}

Arsitektur posmodern merupakan campuran dan turunan elemen-elemen yang saling bertentangan, seperti gaya historis dan kontemporer dan campuran antara seni tinggi dan budaya populer. Hukum relatif pada arsitektur post-modern membebaskan perancang menuangkan apa yang ada dan dirasa benar olehnya. Dimana bangunan adalah bentuk fisik dari olah pikir para perancang. Charles Jencks dengan bukunya "The Language of Postmodern". Architecture (1975) menyebut postmodern sebagai upaya untuk mencari pluralism gaya arsitektur setelah ratusan tahun terkurung satu gaya. Berdasarkan langgam ini, bentuk bangunan berhak dibebaskan dan sepenuhnya diserahkan pada arsitek local untuk berekspresi dan berkreasiatas bentuk dan isi bangunan pada titik kedaerahan mereka berpijak. Jika melihat hal ini, maka paham regionalism suatu daerah sangat diangkat pada arsitektur-postmodern. Post-modernisme merupakan gaya arsitektur yang mencampurkan tradisi dan masa lalu, dengan mengangkat langgam arsitektur regionalisme. Berdasarkan langgam ini, bentuk bangunan berhak dibebaskan dan sepenuhnya diserahkan pada arsitek lokal untuk berekspresi dan berkreasi atas bentuk dan isi bangunan pada titik kedaerahan mereka berpijak. Kedaerahan yang dimaksud berkaitan dengan budaya, iklim dan teknologi pada masanya (Curtis,1985).

\section{Prinsip Arsitektur Postmodern}

Adapun pengertian ide-ide desain dalam Arsitektur postmodern yaitu suatu gagasan perancangan yang mendasari Arsitektur postmodern. Jencks menjelaskan bahwa ciri dari post modern dibagi berdasarkan ideologi, style dan metoda. Jadi dalam pembahasan Arsitektur postmodern, ideologi adalah konsep yang memberikan arah agar pemahaman arsitektur postmodern bisa lebih terarah dan sistematis. Kemudian Stylitic (ragam) adalah Gaya adalah suatu ragam (cara, rupa, bentuk, dan sebagainya) yang khusus. Pengertian gaya-gaya dalam arsitektur postmodern adalah suatu pemahaman bentuk, cara, rupa dan sebagainya yang khusus mengenai arsitektur. Kemudian Metoda ataupun cara terhadap suatu gagasan perancangan.

Sedangkan menurut (Sukada, 1988) bahwa ciri-ciri umum arsitektur post-modern adalah: (1) Mengandung unsur-unsur komunikatif yang bersifat lokal atau popular; (2) Membangkitkan kembali kenangan kembali historic; (3) Berkonstek urban; (4) Menerapkan kembali teknik ornamentasi; (5) Bersifat representasional; (6) Berwujud metaforik (dapat berarti dari bentuk lain); (7) Dihasilkan dari 
partispasi; (8) Mencerminkan aspirasi umum; (9) Bersifat plural dan (10) Bersifat ekletik. Adapun ciri yang telah dijabarkan dapat kita liihat pada ulasan/studi kasus bangunan postmodern berikut:

1. Vanna House - Robert Venturi

Pada dasarnya, bentuk bangunan ini sangat sederhana (Gambar 1). Seorang sejarawan arsitektur Vincent Scully mengatakan kontribusi bangunan sederhana ini menggemparkan dunia arsitektur pada abad duapuluh. Pada masa tersebut, Venturi melawan norma/aturan-aturan yang sudah ada. Fasad depan sangat monumental. bentuk jendela yang kotak pada sisi kanan dan kiri dibentuk tidak simetris dan berbeda ukuran. Elemen non-strukturalnya berupa ornamen lengkungan yang diaplikasikan pada bangunan sangat menarik perhatian. Hal tersebut merupakan memanipulasi elemen arsitektur yang menunjukkan skala bangunan.

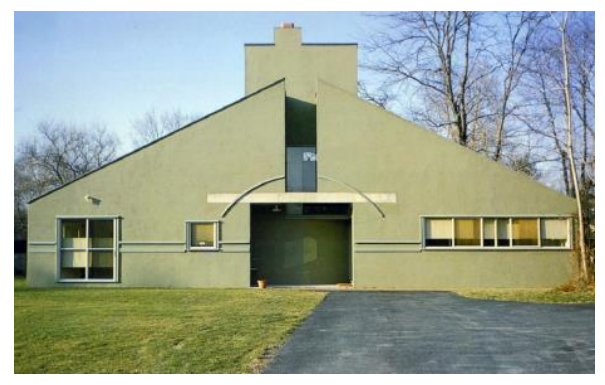

Gambar 1. Vanna House

2. Portland Building - Micheal Graves

Portland Building adalah sebuah bangunan kantor kotamadya yang memilik 15 lantai yang terletak di pusat kota Portland, Oregon. Bangunan ini merupakan bangunan tinggi yang pertama yang membantah teori-teori arsitektur modern yang berkembang pada masa itu. Tampilan khas Michael Graves pada Portland Building (Gambar 2) berupa dengan penggunaan dari berbagai bahan yang bertekstur dan warna, jendela dengan ukuran yang kecil, dan penyertaan dekoratif yang berkembang dan menonjol sehingga menghadirkan sebuah visualisasi yang sangat kontras dengan gaya arsitektur yang paling umum digunakan untuk bangunan kantor pada saat itu.

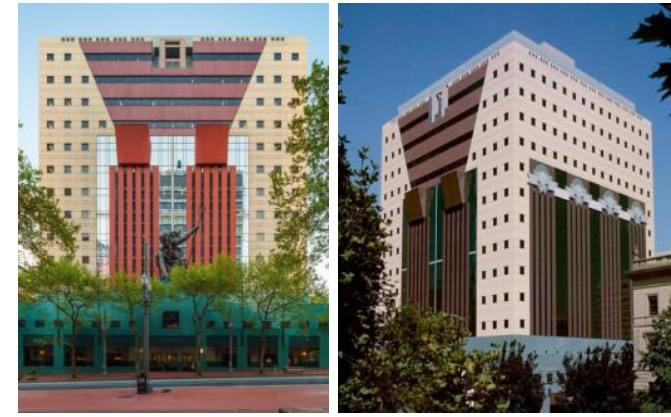

Gambar 2. Portland Building

\section{Arsitektur Postmodern Kota Medan}

Kota Medan termasuk salah satu kota berkembang di Indonesia. Perkembangan yang terjadi memiliki kaitan erat dengan kebun tembakau Deli di Sumatera Utara. Dimana pada masa tersebut dipindahkannya ibukota residensi Sumatera Timur ke Medan sehingga pembangunan infrastruktur pun dimulai (Sinar, 2001). Mulai dari bangunan publik sampai hunian pun mulai menjamuri kota ini. Dalam tulisannya Sinar menjelaskan pada tahun 1881 berdiri sebuah perusahan kereta api, yaitu Spoorweg Maatschappij dan sarana telepon pada 1900 untuk mendukung kemajuan dagang perkebunan tembakau. Perlunya perputaraan uang pada perusahaan sehingga berdirilah cabang The Chartered Bank pada tahun 1887 sedangkan pada tahun 1988 dibangunlah Medan Hotel. Semakin berkembangnya kebutuhan, sehingga fasilitas pelabuhan dan gedung-gedung perkapalan di Belawan pun dibangun pada tahun 1889. Pembangunan yang terjadi pada masa tersebut tentunya menganut paham dan nilainilai arsitektur yang diaplikasikan pada bangunan oleh perancangnya. Jika melihat kebelakang, perkembangan arsitektur pada kota ini juga dimulai dari arsitektur klasik sampai art deco yang aplikasinya sangat menyesuaikan iklim tropis.

Perkembangan pembangunan sejalan dengan berkembangnya konsep dan gaya bangunan. Dari bangunan publik, multifungsi dan hunian. Beberpa bangunan fungsi huni di Kota Medan yang dapat merepresentasikan bahwa perkembangan pembangunan rumah tinggal adalah Perumahan Setia Budi Indah di Medan Sunggal, Medan. Lamanya kawasan ini yang telah menjadi kawasan perumahan, membuat adanya penggabungan unsur lama dan baru. Hal tersebut dapat dilihat pada rumah tinggal kawasan ini. Keberagaman jenis bentuk, fasad, dan gaya hunian yang ada pada 
kawasasan perumahan ini merujuk kepada arsitektur postmodern.

\section{Tinjauan Konsep Bangunan}

Melihat beragamnya bentuk, desain dan fasad bangunan yang ada dapat disimpulkan bahwa kawasan perumahan ini mengikuti perkembangan arsitektur. Kebanyakan dari bangunan menganut unsur-unsur modern. Namun, masyarakat tetap memasukkan ornamen tambahan yang dianggap berfungsi untuk memperindah bentuk dan fasad bangunan. Ornamen tersebut biasanya diletakkan pada jendela, pintu, dinding dan kolom fasad. Selain berfungsi untuk memperindah, tambahan non fungsional tadi juga dianggap sebagai daya tarik bangunan yang mereka miliki. Prioritas bangunan juga tidak hanya berkiblat pada keindahan. Masyarakat tetap menyesuaikan bangunan dengan lingkungan sekitar. Hal tersebut dapat dilihat banyaknya bangunan yang tetap menggunakan atap miring pada bangunan, jendela dan ventilasi udara.

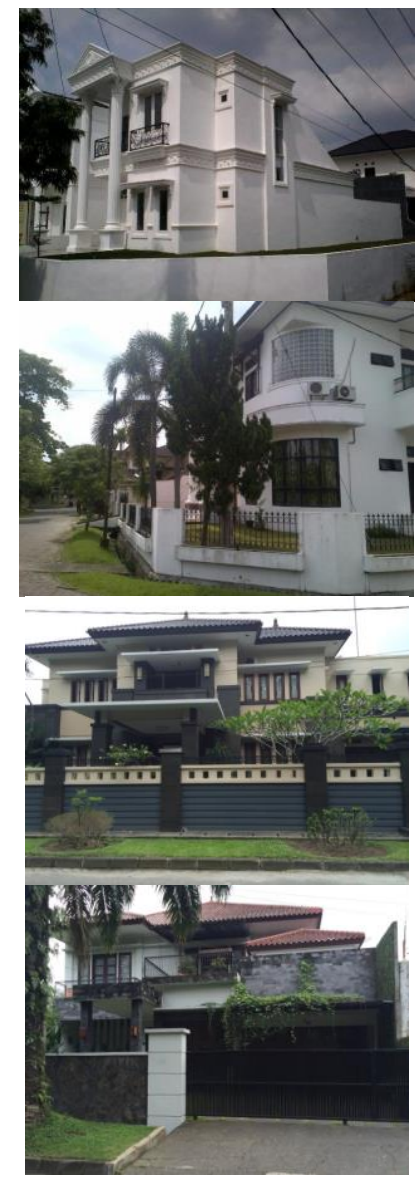

Gambar 3. Beberapa Bentukan Bangunan

\section{Tinjauan Unsur Fasad}

Konsep bangunan postmodern terlihat sekali menguasai bangunan rumah tinggal yang ada pada kawasan ini. Pengembangan material kini dengan penyesuaian lokal dan ornamen (gambar 4) menjadi karakteristik rumah tinggal pada kawasan ini. Hal tersebut dapat dilihat dari penggunaan unsur yang melekat pada fasad. Pada bangunan modern, bentuk geometris menjadi suatu keharusan. Namun, bangunan rumah tinggal yang ada pada kawasan ini menunjukkan penggabungan bentukan dalam fasadnya. Adanya lengkungan-lengkungan yang diletakkan pada (Gambar 4) telah mendominasi dan memberikan kesan pada bangunan.

Unsur lokalitas juga masih diterapkan jika melihat overstek miring berbahan genting dan kusen kayu pada bangunan dua lantai tersebut.

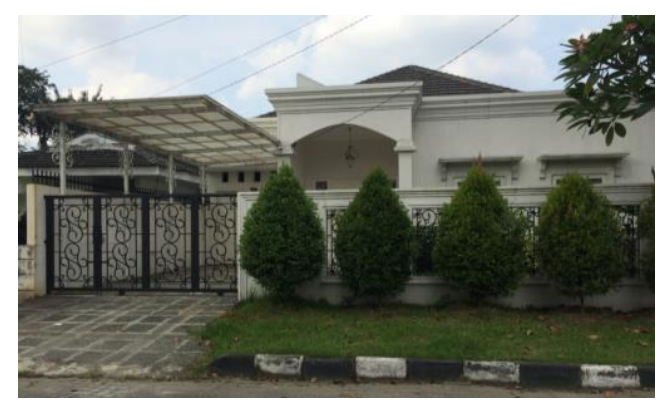

Gambar 4. Dominasi Warna Putih dan Ornamen Membentuk Karakter Bangunan

Bentukan lengkung juga tidak hanya diletakkan pada fasad (Gambar 5), namun menjadi bentukan bangunan. Jendela besar yang hampir memenuhi sisi dinding lengkung, tetap diberikan overstek untuk menghalau teritisan air dikala hujan.

Ornamen pendukung juga diberikan pemilik untuk memperindah dan menjadikan sudut ini sebagai point of view dari luar.

Ornemen tambahan juga tidak hanya diberikan pada sisi lengking. Jika kita memperhatikan yang ada pada dinding bukanlah kolom (Gambar 6). Hal tersebut dikarenakan kolom tersebut tidak diteruskan keatas. Jika dilihat lebih lanjut maka ornamen tersebut hampir sama dengan kolom-kolom yang ada pada Sainsbury Wing of the National Gallery, London. 


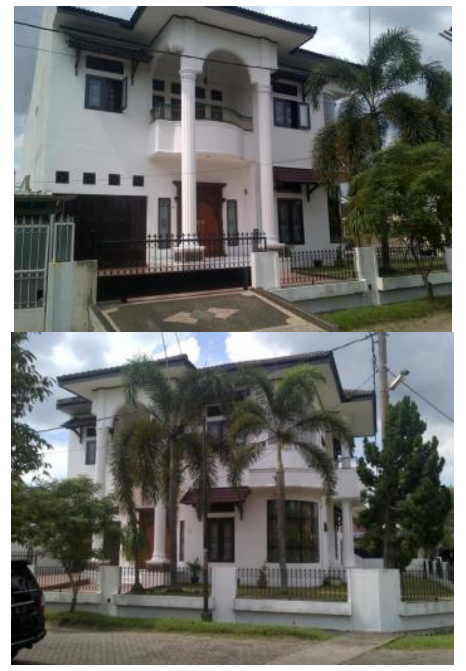

Gambar 5. Penggunaan Bentukan Lengkung dan Material Lokal pada Bangunan

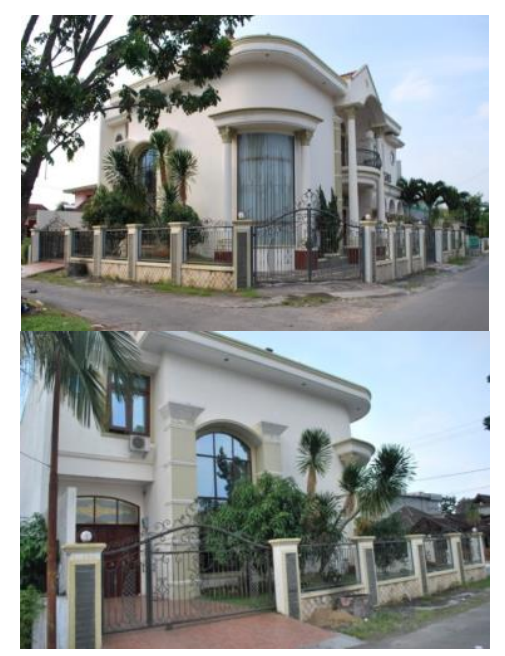

Gambar 6. Ornemen Tambahan pada Fasad Bangunan

\section{Tinjauan Material dan Warna}

Melihat warna dan material bangunan, dapat dilihat dan dirasakan bahwa perancang dan penghuni mengininkan adanya tema yang akan menjadikan karakter bangunan tercipta. Warna-warna yang dipakai didominasi putih dan warna tanah. Material yang digunakan juga banyak menggunakan material lokal seperti batu alam dan kayu (Gambar 7).
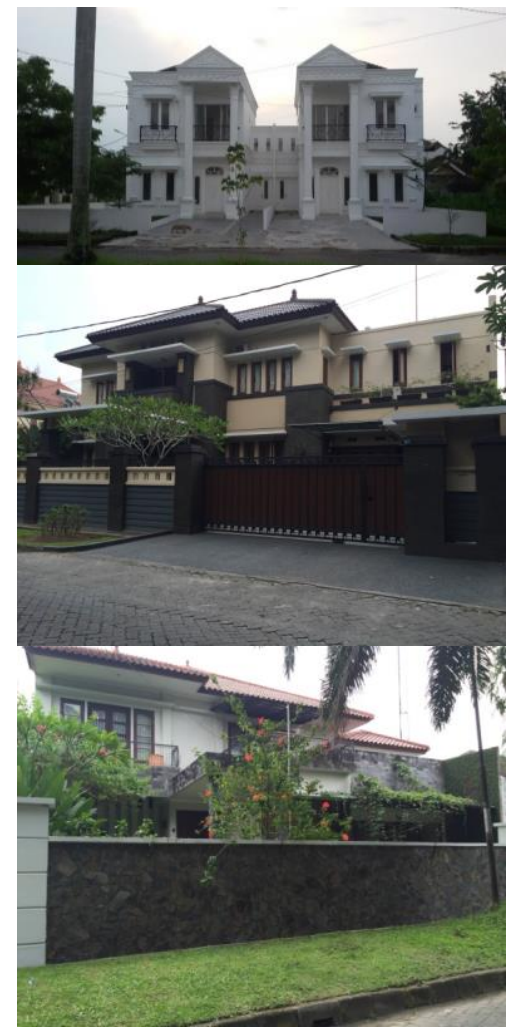

Gambar 7. Penggunaan Material dan Warna Sebagai Pembentuk Karakter Bangunan

\section{Kajian Prinsip Postmodern pada Komplek Taman Setia Budi Indah}

Dari hasil analisa yang dilakukan, dapat dilihat bahwa banguna rumah tinggal yang ada pada kawasan Perumahan Setia Budi Indah Medan menganut unsur-unsur arsitektur postmodern. Hal tersebut dapat dilihat dari idiologi dalam mendesai yang dapat memadukan dua jenis arsitektur. Seperti perpaduan modern dan tradisional, perpaduan dengan lokalitas dan lingkungans sekitar. Dalam postmodern hal tersebut disebut dengan double coding of style. Perpaduan tersebut juga memadukan apa yang diinginkan oleh penghuni yang diterjemahkan perancang dalam bentuk bangunan.

Metodayang dipakai pada bangunan kawasan perumahan ini hampir rata-rata mengusung contekstual urban form dan funcional mixing. Penggabungan kebutuuhan dan fungsi yang ada dalam satu bangunan dapat dilihat dengan sangat jelas. Sedangkan style yang dipakai adalah bangunan tersebut menonjolkan bentuk bentuk konvensional yang digabungkan dengan bentukan rumit untuk menunjukkan dan dapat ditangkap oleh mata keberadaannya. Melihat ideologi, metoda dan 
gaya yang dipakai, benar adanya bahwa bangunan pada kawasan ini telah menyerap unsur-unsur postmodern

\section{KESIMPULAN}

Arsitektur postmodern bermula dari kejenuhan masyarakat terhadap arsitektur modern, maka timbullah gerakan pembenahan dari para arsitek. Dimana posmodern berfokus pada aspek-aspek semantik (simbolisme dan makna). Postmodern merupakan gaya arsitektur yang mencampurkan tradisi dan masa lalu, dengan mengangkat langgam arsitektur regionalisme.

Arsitektur postmodern tidak hanya berkembang, namun tumbuh menjadi bagian dari masyarakat. Sumbangsih dan gaya post modern bahkan hadir pada bangunan pribadi dengan fungsi huni. Penyesuaian terhadap lingkungan dan unsur tradisinal juga diterapkan pada bangunan, seperti pengaplikasian atap miring, overstek panjang, penutup atap berupa genting dan unsur-unsur ornamen modern pada bangunan. Dari hasil observasi yang berlandaskan tinjauan teoritis, masyarakat Kota Medan memasukkan nilai seni estetika kedalam huniannya. Sehingga dapat disimpulkan bahwa rumah tinggal di Kota Medan kini tidak hanya dianggap sebagai tempat berlindung daari panas dan hujan saja.

\section{Daftar Pustaka}

Adam, Jerry dan Swandara, Rizki (2014) Kajian Desain Fasad Baru Grand Royal Panghegar Bandung Dalam Perspektif Arsitektur Modern, Jurnal Online Institut Teknologi Nasional, Vol. 1, No.4

Curtis, Wlian (1985) Regionalism in Architecture, Robert Powel, Concept Media, Singapura

Ikhwanuddin (2004). Menggali Pemikiran Posmodernisme dalam Arsitektur. GMUP: Yogyakarta.

Jencks, Charles (1977) The Language of Postmodern Architecture, Rizzoli, New York.
Keraf, Alexander Sonny (2002) Etika Pengelolaan Sumber Daya Alam dan Lingkungan Hidup. Jakarta, Unika Atma Jaya.

Kahl, Douglas (2008) Robert Venturi and His Contributions to Postmodern Architecture, Oshkosh Scholar, Vol.3, Hal 55-63

Ridwan, N. A. (2007) Landasan Keilmuan Kearifan Lokal. Purwokerto, P3M STAIN, IBDA, Vol. 5, No. 1

Sinar, Tengku Luckman (2001) Sejarah Medan Tempo Doeloe. Medan: Perwira.

Soedigdo, Doddy (Juli, 2010) Arsitektur Regionalisme (Tradisional Modern), Vol. 5 No.1.

Wiondoamineso, R.A (1991) Regionalisme dalam Arsitektur Indonesia: Sebuah Harapan. Yayasan Rupadatu, Yogyakarta 